\title{
Human Resource Management under Enterprise Strategic Perspective
}

\author{
Yan Yue \\ Shijiazhuang Staff University, Shijiazhuang, 050000, China
}

Keywords: enterprise strategy; human resource management; connotation; function; approach

\begin{abstract}
Human resource management is an important constituent part of enterprise management. Scientific and reasonable management of human resources concerns implementation of enterprise development strategy, enterprise survival and long-term development. This paper states the connotation of human resource management, defines the concept of strategic human resource management, then analyzes the key functions of human resource management in enterprise strategic development and finally deeply studies human resource management strategies under enterprise strategic perspective.
\end{abstract}

\section{Introduction}

Enterprise strategy is the generic term of various enterprise strategies to seek survival and development ${ }^{[1]}$. Human resource management is a management activity conducted by enterprises to realize strategic needs. To give play to the value of human resource management in enterprise strategic management, human resource management system must be used to realize effective deployment and application of internal and external relevant human resources. To correctly cognize key functions of enterprise strategic development in human resource management and study enterprise human resource management strategy from five aspects (management idea, training system, performance appraisal system, incentive and constraint mechanism and informatization management) on the basis of the perspective of enterprise strategy has important significance for driving long-term development of enterprises.

\section{Important significance of human resource management in enterprise strategic development}

All activities of human resource management centre on enterprise strategic demand. Construction of scientific, rational and effective human resource management system under enterprise strategic perspective can realize optimization and maximization of human capital value, drive and promote enterprises to enhance core competitiveness. The important significance of human resource management in enterprise strategic development is mainly displayed in the following three aspects:

\subsection{Human resource management is beneficial to improving employees' work efficiency}

Under enterprise strategic perspective, to comprehensively achieve strategic targets, the improvement of employees' work efficiency is the vital task [2]. Effective human resource management is a significant approach to promote employees to boost work efficiency. Under enterprise strategic perspective, human resource management should be based on employees' needs and growth, take win-win development of employees and enterprises as the purpose and closely connect personal value and development of employees with future development of enterprises through providing employees with on-the-job training and further studies complying with their features and needs. It is required to construct people-oriented working environment, cultivate employees' enthusiasm, initiative and creativity.

Under the condition of complying with overall interests, enterprises can implement post rotation system so that employees can generate feeling of freshness, which cannot not just effectively improve employees' work efficiency, but also cultivate their adaptive capacity through post rotation. In different posts, employees can keep work enthusiasm and creativity and serve for improvement of enterprise economic benefit.

\subsection{Human resource management is the need of enterprise strategic developmental}

Scientific and reasonable human resource management from the perspective of enterprise 
strategic management can satisfy the needs of enterprise development strategy and contribute to realization of enterprise strategic goals. Human resource management regards enterprise strategic purpose as the objective. Through improving employee's quality and ability, properly recruiting employees complying with enterprise strategic needs and supplying scientific, perfect and flexible organizational system, enterprises can fully motivate employees' potential, provide support, male employees continuously boost their quality and ability and devote themselves to enterprise development and ensure flexibility and provide help for enterprises to realize strategic objectives in future fierce competitions situations.

\subsection{Human resources concern enterprise strategic development and success or failure}

Human resource is the first resource and also the most critical and scarce resource in enterprise strategic development [3]. Under the perspective of enterprise strategy, it is required to develop human resources in combination of strategic needs, cultivate human resource library and formulate scarce strategies under the guidance of enterprise strategic goal. Rational deployment, development and application of human resources are the core elements to drive better and faster development of enterprises and also key elements to decide enterprise future development and the success in competitions.

\section{Study on human resource management strategies under enterprise strategic perspective}

\subsection{To establish the idea of strategic human resources management}

The competitions in current era are actually competitions for personnel. Only when enterprises own strong human resources can they create greater values so as to improve enterprise competitiveness and promote long-term stable development. Nowadays, market environment is ever-changing, so enterprise human resource management also continuously improves. To realize long-term development goals, human resource management must be oriented to strategies, rationally apply, develop and integrate enterprise human resource and form perfect strategic human resource management system so as to enhance competition advantage and realize optimal performance.

Thus, enterprises must establish strategic human resource management idea, seek out proper management methods under the condition of various changing factors and guide long-term development. Under enterprise strategic perspective, human resource management must always adhere to people first, regard people as the staring point and ending point of everything, closely connect employees' benefits and enterprises' benefits, promote comprehensive and sustainable development of employees and complete enterprise strategic goals. Only under the guidance of strategic human resources management, enterprises can play the benefits of vast employees in the important position, really respect and care for employees, create personnel management enterprise atmosphere for employees and better retain personnel ${ }^{[4]}$.

\subsection{To construct scientific training education system}

Firstly, perfect enterprise personnel training education system, under the guidance of enterprise strategic development

As enterprises develop continuously, their requirements for employees also become increasingly high. Meanwhile, employees' job contents also change. Besides, enterprises' business also upgrades continuously. This requires enhancing new content training for employees and improving their business level so as to adapt enterprise development. Enterprises can select multiple training modes according to their development, including internal training and external training or on-the-job training and off-job training.

Secondly, training contents should be people-oriented and pay attention to combining development of professional career.

Enterprises should formulae perfect training system suitable for employees' development, combine post needs and employees' individual interest to choose corresponding training contents, closely connect enterprise training with individual development, continuously improve employees; woke performance and work skills, make employees clearly see the promotion and development space supplied by enterprises and stimulate them to better develop in the enterprises. In this way, 
enterprise development and employee development can be fused to form long-term cooperation relationship and promote employee development in the enterprises.

Thirdly, training results are considered during employee salary adjustment and post adjustment.

Human resource management department should give correct evaluation of training contents and effects after the training, carefully record employees' work performance before and after the training, fully affirm the employees making progress and give certain post promotion and adjustment according to employee's actual work. Since enterprises input manpower and financial resources in training activities, employees also spend much time and energy, if training contents have no effect on employees and no post change is made, employees' participation enthusiasm will be directly influenced. So, enterprises should fully affirm the employees making significant progress and make adjustments in salary and post.

\subsection{To construct systematical performance appraisal system}

Performance appraisal means enterprises evaluate and measure employees' work performance in various aspects objectively, including ability, potential, morality and character, so as to give correct positioning. Aiming at different employees and posts such as technical personnel, management personnel, workers at the production line and customer service staffs, evaluation standards and procedures should be also different. To establish open performance appraisal system should start with the following two aspects:

Firstly, specify the importance of human resource performance appraisal and arouse enough attention of the management layer to human resource performance appraisal. Currently, management ideas of many enterprises are old-fashioned and cannot adapt the system of modern market economy. In such case, to perfect various systems and establish effective human resource performance appraisal system, enterprise leaders need to see important functions of human resource management and realize enterprise development needs the guarantee of perfection of human resource performance appraisal system. In this way, enterprises can promote long-term development and mobilize employees' work enthusiasm. If relevant leaders do not pay attention to enterprise systems, they will not give play to huge functions.

Secondly, establish effective performance evaluation mechanism

Enterprises should carefully analyze development strategic goals, formulate suitable post development plans, make post setting meet enterprise development needs, provide important support for completing enterprise development strategic goals and make employees feel the importance of their posts so as to better contribute to enterprise development. Enterprises mainly establish effective performance appraisal mechanism from the following aspects: firstly, overall evaluate employees horizontally and vertically; secondly, quantify and detail employee performance appraisal; thirdly, comprehensively evaluate and summarize performance appraisal results. Each department must combine performance appraisal results to rethink and improve shortcomings, adjust working methods, formulate feasible work plans, report work plans and work summary to leaders, listen to leaders' views and reach consistent goals.

\subsection{To stimulate sharing enterprise operation achievements and regard internal and external constraints as the guarantee}

Firstly, share enterprise operation achievements and form effective incentive for personnel

Making human resources share enterprise operation achievements is the most effective incentive of human resources. Material incentive and non-material incentive are two ways to share achievements. Material incentive mainly puts particular emphasis on reconstruction of human resource salary system and gives corresponding salary or warfare incentive policy according to employees' contributions and benefits they create. Enterprises should make personnel gain certain benefits according to their contributions. Research results of scientific and technological personnel should serve as a factor of salary distribution. Regardless of the whole department or individuals, as long as they create income for enterprises, they should be encouraged with materials. Non-material incentive refers to other incentives apart from salary award. Non-material incentive is reflected in paying attention to employees' career development and providing the opportunities of further education, advanced studies and overseas studies. Meanwhile, it is required to construct 
learning-based organization in the enterprise and provide environmental support for employees to learn knowledge and train skills.

Secondly, perfect human resource restriction mechanism and maximize functions of human resource management

Enterprise human resource restriction mechanism contains internal constraint and external constraint. Based on enterprise development strategy, enhancement of internal constraint of human resources should mainly start with contract constraint, organization constraint, regulation constraint and preference constraint. The contract is used to standardize employees' post duties; regulations are used to rationally constrain behaviors; preference constraint is used to give play to employees' respective advantages. External constraint of human resources mainly starts with legal constraint, social moral constraint, human market constraint and social group constraint. External constraint can standardize and adjust employees' behaviors and make them advance along the direction beneficial to joint development of employees and enterprises. Internal constraint and external constraint can assist enterprise human resource management and maximize functions of human resources.

\subsection{To enhance development and construction of enterprise human resource management informatization}

In informatization era, acceleration of human resource informatization construction has become an inevitable choice of enterprises to enhance their core competitiveness. The following should be done:

Under enterprise strategic perspective, enterprises must set up human resource management system with sound functions and wide coverage. Through effective informatization management system, the information about staff structure and post requirements can be retrieved and inquired clearly, visually and effectively. Meanwhile, personnel information management system can be used. According to post allocation requirements, the system will automatically screen qualified employees and provide reference for enterprises' personnel turnover and application so as to rationalize human resource turnover and allocation. Besides, human resource informatization management can be applied to provide convenience for leaders to inquire and release information.

At the same time, human resource management system should combine enterprise internal management features to set up network coordination platform and realize network-based management of work procedures. In addition, organizational framework, performance appraisal, personnel assessment, contract management, cadre assessment, salary system and other functions should be integrated into a system to realize human resource data management. This will greatly improve speed and efficiency of human resource management, reduce tedious links in traditional human resource management and contribute to improving enterprise competitiveness.

\section{Conclusions}

Under enterprise strategic perspective, enterprises must study and analyze human resource management system and mechanism, look for adverse factors hindering human resource management efficiency and quality, solve them in a scientific and reasonable manner and continuously seek improvement and innovation of human resource management system. Based on enterprise strategic perspective, enterprises should fully realize significance of human resource management in enterprise strategic development, update human resource management idea, continuously perfect human resource appraisal, incentive and constrain mechanisms and accelerate human resource management informatization construction. We believe in the process of continuous exploration, introspection, improvement and innovation, enterprise core competitiveness will be effectively improved to drive healthy and rapid development of enterprises and contribute more to socialist construction.

\section{References}

[1] Gong Huaru, Study on enterprise strategic human resource management mode [J]. Human 
Resource Management, 2014, 02:65

[2] Xu Ning, 5P-based analysis of strategic human resource management thought of Chinese private enterprises in different life cycles [J]. Special Zone Economy, 2013, 08:138-140

[3] Li Zhi, On strategic human resource management of small and micro-enterprises under psychological capital horizon [J]. Commercial Times, 2013,23:86-87

[4] ma Xuemin, On construction of incentive mechanism for enterprise strategic human resources [J]. Modern Business, 2013, 29:83. 